\title{
Inoculation of maize with phosphate solubilizing bacteria: effect on plant growth and yield
}

\author{
E. Viruel ${ }^{1,2 *}$ L. E. Erazzú ${ }^{3,4}$, L. Martínez Calsina ${ }^{1}$, M. A. Ferrero ${ }^{2,5}$, M. E. Lucca ${ }^{2,5}$, F. Siñeriz ${ }^{2,5}$ \\ ${ }^{1}$ Instituto de Investigación Animal del Chaco Semiárido (IIACS), Centro de Investigaciones Agropecuarias \\ (CIAP), Instituto Nacional de Tecnología Agropecuaria (INTA), Leales, Tucumán, Argentina. \\ *Corresponding author: viruel.emilce@inta.gob.ar \\ ${ }^{2}$ Consejo Nacional de Investigaciones de Cientificas y Tecnológicas (CONICET), Planta Piloto de Procesos \\ Industriales y Microbiológicos (PROIMI), Tucumán, Argentina. \\ ${ }^{3}$ Estación Experimental Agropecuaria Famaillá, INTA, Famaillá, Tucumán, Argentina \\ ${ }^{4}$ Cátedra de Genética. Facultad de Agronomía y Zootecnia, Universidad Nacional de Tucumán (UNT), El \\ Manantial, Tucumán, Argentina. \\ ${ }^{5}$ Cátedra de Microbiología Superior, Facultad de Bioquímica, Química y Farmacia, Tucumán, Argentina.
}

\begin{abstract}
Phosphate-Solubilizing Bacteria (PSB) improve plant growth, yield and phosphorus content of several crops, and may be used as bioinoculant to enhance sustainable production. We evaluated the response of maize (Zea mays L.) to PSB inoculation under controlled and field conditions in Tucumán, Argentina. A pot culture experiment was conducted to investigate the effects of seven previously isolated PSB on early development of plants. Seeds were treated with each bacterial strain, and seedlings were harvested 30 days after inoculation. All strains showed a positive effect on plant growth. A significant increment in plant height (45\%), shoot dry weight (40\%) was determined in plants treated with Pseudomonas tolaasii IEXb, while Pseudomonas koreensis SP28 has remarkably increased P content compared to the uninoculated control. IEXb strain was selected and evaluated under field conditions in combination with triple superphosphate (TSP) as P fertilizer. The presence of IEXb strain stimulated seedling emergence (8\%), shoot length (19\%), grain yield (44\%), 1000-grain weight (18\%), total dry biomass (32\%) and P content (56\%) of maize plants. In general, P. tolaasii IEXb inoculation was more efficient as bioinoculant without $\mathrm{P}$ fertilizer than with TSP. These results provide baseline information for future studies of $P$. tolaasii $\mathrm{IEXb}$ as bioinoculant to promote an eco-friendly and sustainable agriculture.
\end{abstract}

Keywords: Bioinoculant, phosphate solubilizing bacteria, Pseudomonas tolaasii IEXb, Zea mays L., Growth promotion, sustainable agriculture 


\section{Abbreviations:}

PGPR Plant growth-promoting

rhizobacteria

PSB Phosphate solubilizing

bacteria

TSP Triple superphosphate

IAA Indole-3-acetic acid

DAS Days after sowing

\section{Introduction}

Phosphorus (P), one of the main plant nutrients, is essential for plant growth and development. It is involved in several key plant functions, such as energy metabolism, photosynthesis, respiration, nitrogen fixation, enzyme regulation, nutrient movement within the plant and transfer of genetic characteristics (DNA) from one generation to the next. Therefore, $\mathrm{P}$ is important in cell division and development of new tissue (Hameeda et al., 2008). Plants absorb $\mathrm{P}$ either as $\mathrm{HPO}_{4}{ }^{2}$ or $\mathrm{H}_{2} \mathrm{PO}_{4}{ }^{1-}$ ions. However, in most soils, the concentration of soluble orthophosphates is low, normally $1 \mathrm{mg} \mathrm{kg} \mathrm{kg}^{-1}$ or lower (10 $\mathrm{M} \mathrm{H}_{2} \mathrm{PO}_{4}{ }^{1-}$; Rodríguez and Fraga, 1999) and must be replenished from other pools of soil $\mathrm{P}$ to meet plant requirements (Richardson et al., 2009). To counterbalance this nutritional deficiency in crops, $\mathrm{P}$ is supplemented via different chemical fertilizer formulations. Only a low percentage of these agrochemicals can be used efficiently by plants, with the remaining fraction being rapidly converted into insoluble complexes in the rhizosphere, without the expected impact on agricultural yield (Fernández et al., 2012). In this era of sustainable agricultural production, the role of the rhizosphere has become important given the need to restrict fertilizer use and therefore improve the energetic balance of the system. Rhizosphere activity allows the transformation, mobilization and solubilization of nutrients from a limited pool in the soil and subsequent uptake of essential nutrients by plants to achieve crop genetic potential (Hinsinger et al., 2011). In the rhizosphere, microorganisms interact with plants in several ways. Bacteria that act positively on plant growth and development, through direct or indirect mechanisms, are collectively known as Plant Growth-Promoting Rhizobacteria (PGPR) (Kloepper and Schroth, 1981). This group includes PhosphateSolubilizing Bacteria (PSB), which are rhizobacteria that convert insoluble phosphates into soluble forms through acidification, chelation, exchange reactions and production of organic acids (Rodríguez and Fraga 1999). They are found in soil but usually they are not enough in the rhizosphere of plants. Therefore, inoculation of plants by a target microorganism at higher concentration than that normally found in soil is necessary to take advantage of the property of phosphate solubilization for plant yield enhancement (Vessey, 2003). Accordingly, several works reported that inoculation with PSB belonging to the genera Achromobacter, Agrobacterium, Aerobacter, Bacillus, Burkholderia, Escherichia, Erwinia, Enterobacter, Flavobacterium, Microccocus, Pseudomonas, Paenibacillus, Pantoea, Serratia and Rhizobium resulted in improved growth, yield and $\mathrm{P}$ uptake in several crops (Ahemad and Kha 2010; Castagno et al., 2011; Hameeda et 
al., 2008; Hu et al., 2010; Minaxi et al., 2013; Selvakumar et al., 2008; 2011; Yu et al., 2012). In Argentina, agricultural production generates a significant income to the country. Indeed, more than $50 \%$ of all Argentine exports come from the agricultural sector (Tomei and Upham, 2011). As a consequence of the intensive agricultural activity, fertilizer use in the 2010/11 cropping season was approximately 3.37 million $\mathrm{t}$, being $5 \%$ higher than in 2009/2010 (Velasco et al., 2012). Indiscriminate use of chemical fertilizers is producing negative environmental effects, such as nitrogen $(\mathrm{N})$ leaching and run-off, and P-fixation in the soil (Adesemoye and Kloepper, 2009). The use of bioinoculants may be a better alternative and a complement to chemical fertilizers, since they promote rhizospheric activity, are economical and environmentally friendly, and may be easily obtained from the rhizosphere.

In our laboratory, we isolated seven PSB strains identified as Serratia marcescens EV1, Pantoea eucalypti EV2, Pantoea agglomerans EV3, Pantoea eucalypti EV4, Pseudomonas tolaasii IEXb, Enterobacter aerogenes IEY and Pseudomonas koreensis SP28, all of them from Puna grassland, north-western Argentina (Viruel et al., 2011). These bacterial strains present several plant growth promotion traits, such as $\mathrm{P}$ solubilization (by acidification and phosphatase production) and production of Indole-3-acetic acid (IAA) and siderophore. The objective of this study was to screen a bacterial strain able to enhance growth and yield in maize crop, both in growth chamber and under field conditions, as a first stage in the development of commercial formulations of bioinoculants.

\section{Materials and Methods}

\subsection{Plant experiments}

\subsubsection{Growth chamber trial}

To evaluate the use of bacteria as bioinoculants for promoting growth in maize, seven bacterial strains previously selected for their in vitro characteristics (Viruel et al., 2011) were tested in growth chamber. All strains were maintained at $-20^{\circ} \mathrm{C}$ in Luria Bertani broth containing $20 \%\left(\mathrm{v} \mathrm{v}^{-1}\right)$ glycerol. They were transferred to synthetic medium under aseptic conditions (Viruel et al., 2011), and incubated in rotatory shaker for biomass propagation at $150 \mathrm{rpm}$ and $30^{\circ} \mathrm{C}$ during $24 \mathrm{~h}$.

Seeds of hybrid maize (Zea mays L. DK 390 MG RR2 Dekalb ${ }^{\circledR}$ ) were used as host plant to evaluate the performance of PSB. Bacterial cultures $\left(10^{9} \mathrm{CFU} \mathrm{ml}^{-1}\right)$ of each strain were used as bioinoculants at a final concentration of $50 \mathrm{ml}$ $\mathrm{Kg}^{-1}$ seed.

Glass pots $\left(500 \mathrm{~cm}^{3}\right)$ previously sterilized with $20 \%$ sodium hypochlorite solution were filled with sieved $(<2 \mathrm{~mm})$ and sterile soil. Seeds were first sterilized in $80 \%$ ethanol for $2 \mathrm{~min}$ followed by $0.1 \% \mathrm{HgCl}_{2}$ for $10 \mathrm{~min}$; finally, they were rinsed 
10 times in sterile distilled water before bacterial treatment. For inoculation assays, seeds were soaked for $30 \mathrm{~min}$ in the bacterial suspension and placed at the same depth (approximately $2.5 \mathrm{~cm}$ below the soil surface) in all pots. The pots were arranged in a completely randomized factorial design in the growth chamber. Ten replicates (pots) per bacterial inoculum were made. The control treatment consisted of water-treated seeds (without bacteria inoculation). Plants were grown for 30 days under controlled conditions: $25 \pm 3^{\circ} \mathrm{C}$, day-night cycle of 12-12 $\mathrm{h}$ with artificial light (140 $\mu \mathrm{Em}^{-2} \mathrm{~s}^{-1}$ ) and $70 \%$ relative humidity; they were daily watered with sterile water and a modified Hoagland solution (Hoagland and Arnon, 1950), where the $\mathrm{P}$ source was changed by tricalcium phosphate $\left(50 \mathrm{mg} \mathrm{l}^{-1}\right)$. At harvest, the following parameters were recorded in maize plants: height, shoot and root dry weight, and P content (Murphy and Riley, 1962) after digestion in nitric and perchloric acid (Johnson and Ulrich, 1959).

\subsubsection{Field trial}

The experiment was conducted at Instituto de Investigación Animal del Chaco Semiárido (IIACS), INTA Leales, Tucumán, Argentina (2711'34'S 65'14'47’'W, 435 masl) from January to June 2012. The soil was classified as silt loam; at the beginning of the experiment the soil contained $2.39 \%$ of oxidable organic matter (Walkley-Black Method), $0.1 \%$ of total $\mathrm{N}$ (Kjeldhal technique), $16.5 \mathrm{ppm}$ of available P (Bray-Kurtz I Method), 1.54 me $100 \mathrm{~g}^{-1}$ of available K (Morgan Method), $0.5 \%$ of carbonate content (Gasometric Method), $1.5 \mathrm{dS} \mathrm{m} \mathrm{m}^{-1}$ of electrical conductivity of the saturated soil-paste extract and $\mathrm{pH}\left(\mathrm{H}_{2} \mathrm{O}\right.$ 1:2.5) of 8.0. Monthly accumulated rain $(\mathrm{mm})$ and monthly mean daily temperature $\left({ }^{\circ} \mathrm{C}\right.$ ) (Table 1 ) were recorded by the Weather Station Davies Vantage Pro 2 of the IIACS and processed using the software Weatherlink.

Table 1. Monthly accumulated rain and monthly mean daily temperature at the experimental site of field inoculation trial during the crop growing season (Dec-Jul) (Data by IIACS, INTA Leales).

\begin{tabular}{ccc}
\hline Date & $\begin{array}{c}\text { Monthly } \\
\text { accumulated } \\
\text { rain }(\mathrm{mm})\end{array}$ & $\begin{array}{c}\text { Monthly mean } \\
\text { daily } \\
\text { temperature }\left({ }^{\circ} \mathrm{C}\right)\end{array}$ \\
\hline Dec-11 & 89.6 & 24.2 \\
Jan-12 & 220.4 & 24.9 \\
Feb-12 & 273.7 & 23.5 \\
Mar-12 & 103.4 & 22.1 \\
Apr-12 & 63.2 & 20.0 \\
May-12 & 9.0 & 16.2 \\
Jun-12 & 24.0 & 12.4 \\
Jul-12 & 10.0 & 11.4 \\
\hline
\end{tabular}


Based on the growth chamber test results and information in the literature (Brady et al., 2009; Krey et al, 2013), Pseudomonas tolaasii IEXb was selected for field experiment. Seed inoculation was carried out as described above (2.1.1). Four treatments with three replicates were established in completely randomized blocks. Each plot was $8 \mathrm{~m}$ long $\times 3 \mathrm{~m}$ wide, with a distance between rows of $0.52 \mathrm{~m}$. Nitrogen in the form of urea $\left(100 \mathrm{~kg} \mathrm{~N} \mathrm{ha}^{-1}\right)$ was applied in two-split doses (sowing and flowering) to all treatments. Phosphorus (50 kg $\left.\mathrm{P} \mathrm{ha}^{-1}\right)$ was applied as triple superphosphate (TSP) in a single dose at sowing. The experiment consisted of the following treatments: (i) uninoculated control (C), (ii) uninoculated control with $\mathrm{P}$ fertilizer (C + TSP), (iii) P. tolaasii IEXb (IEXb), (iv) $P$. tolaasii with P fertilizer (IEXb + TSP).

The emergence of seedlings was recorded 7 days after sowing (DAS). At harvest (170 DAS), one quadrate $\left(0.25 \mathrm{~m}^{2}\right.$ of plant material) per plot was randomly cut to ground level and plant growth parameters were measured.

Shoot dry weight was determined by drying the plant material at $60^{\circ} \mathrm{C}$ for 5 days. Shoot and cob were separated and grain yield was calculated. For chemical analysis, plant samples were redried at $80^{\circ} \mathrm{C}$ for $48 \mathrm{~h}$ and ground to a powder $(2$ $\mathrm{mm})$. These powders $(0.5 \mathrm{~g})$ were digested and analyzed for P content, as described in 2.1.1.

\subsection{Statistical analysis}

All the recorded data were subjected to an analysis of variance (ANOVA) and means were separated by the Fisher's protected LSD test using the Infostat Analytical Software for Windows (Di Rienzo et al., 2011). A 0.05 significance threshold was used for all statistical tests.

\section{Results}

\subsection{Growth chamber trial}

Results of shoot length, shoot and root dry weight and $\mathrm{P}$ content of plants grown in the growth chamber for all treatments are shown in Figure 1. Under controlled conditions, plants inoculated with $P$. tolaasii IEXb had the highest aerial height, with significant differences compared with the other treatments (Figure 1A). Plants inoculated with this bacterial strain were $45 \%$ taller than uninoculated plants. Treatment with EV4 strain also stimulated growth, with an increase of $38 \%$ with respect to control. Although control plants had the smallest shoot length, there were no significant differences between this treatment and EV1, EV2, EV3 or SP28 inoculation treatments. Shoot dry weight was $40 \%$ higher in plants inoculated with IEXb than in the control treatment, whereas in the IEY inoculation treatment this parameter was $15 \%$ lower than in the control (Figure 1B). Root dry weight of plants inoculated with SP28 was significantly higher than that of the other treatments, being more than double with respect to control plants (Figure 1C).

All bacterial inoculation treatments showed a remarkable increase in plant $\mathrm{P}$ content (Figure 1D). The highest $P$ concentration was found in plants inoculated with SP28 strain $\left(8.1 \mathrm{mg} \mathrm{P} \mathrm{g}^{-1}\right.$ plant), a value that was $145 \%$ higher than that of the control treatment. However, two different types of responses were observed among the remaining inoculation treatments, with an 
intermediate P content for IEXb, EV2 and EV1, and a lower one for EV3, EV4 and IEY.

\subsection{Field trial}

The present results are similar to those reported for inoculation with strains of the genera Pseudomonas and Pantoea on several crops under controlled conditions ( $\mathrm{Hu}$ et al., 2010; Minaxi et al., 2013; Selvakumar et al., 2008; 2009). However, strains of the genus Pantoea are closely related to plant diseases, like Stewart's vascular wilt caused by Pantoea stewartii subsp. stewartii, crown and root gall disease of Gypsophila spp. and beet caused by $P$. agglomerans and $P$. ananatis, which causes a number of diseases on a wide range of hosts, including stem necrosis of rice and brown stalk rot of maize (Brady et al., 2009). Notwithstanding, in our experiment, inoculation with Pantoea eucalypti EV4 did not cause any sign of pathogenesis in maize plants. However, considering this background and the obtained results, the bacterial strain selected to be tested as bioinoculant in the field trial was Pseudomonas tolaasii IEXb.

Significant differences in seedling emergence at 7 DAS were observed among treatments (Figure 2A). The maximum percentage of plant emergence was found in plots inoculated with IEXb strain (89.1\%); this value was $4 \%$ higher than the same bacterial treatment with P fertilizer (IEXb + TSP). Uninoculated plots (C) had the lowest seedling emergence percentage $(80.8 \%)$ and were only $2.2 \%$ lower than the uninoculated plots with $\mathrm{P}$ fertilizer $(\mathrm{C}+\mathrm{TSP})$.

The activity of IEXb strain without TSP had a considerable influence on maize growth; indeed, a 19\% increase in shoot length was recorded with respect to untreated control (C) (Figure $2 \mathrm{~B})$. IEXb + TSP treatment also significantly promoted shoot biomass growth, with an increment of $15 \%$ in shoot length at the end of the experiment. Only inoculated plants, both with and without $\mathrm{P}$ fertilizer, reached shoot lengths of over $250 \mathrm{~cm}$ at harvest. As mentioned above, the lowest shoot length value $(225.3 \mathrm{~cm})$ was recorded in uninoculated plants $(C)$.

Interestingly, the maximum $\mathrm{P}$ content was observed in plants treated with IEXb without TSP (62.8 $\mathrm{g} \mathrm{P} \mathrm{mg}^{-1}$ plant), with significant differences with respect to the counterpart fertilized bacterial treatment (IEXb + TSP: $56.1 \mathrm{~g} \mathrm{P} \mathrm{mg}^{-1}$ plant). The minimum $\mathrm{P}$ content value was determined in uninoculated plants without $P$ fertilizer (C: $40.3 \mathrm{~g}$ $\mathrm{P} \mathrm{mg}^{-1}$ plant). No significant difference was found between control treatments (Figure 2C). 

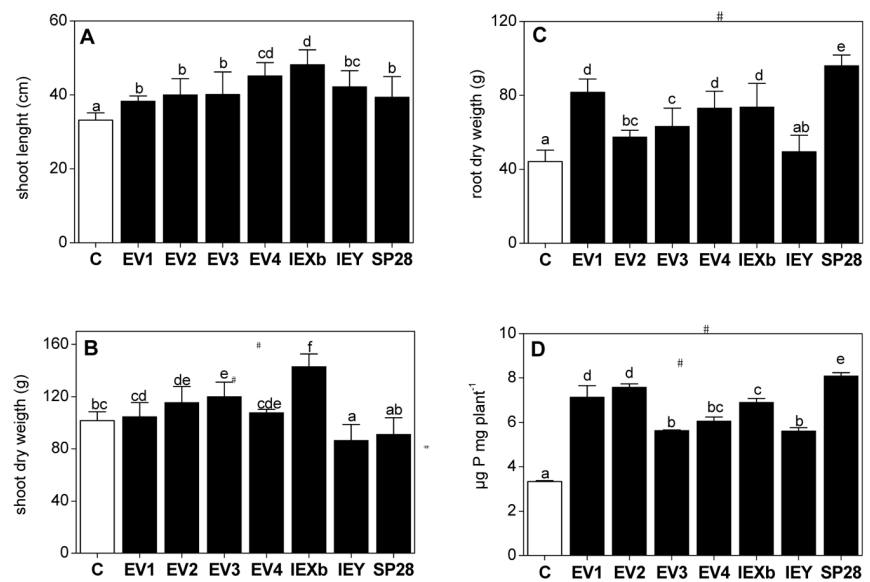

Figure 1. Effects of inoculation with phosphate solubilizing bacteria on shoot length (A), shoot (B) and root (C) dry weight and P content (D) of maize plants grown under controlled conditions, 30 days after sowing. White bar: uninoculated seeds, black bars: inoculated seeds. Data represent mean \pm standard error of mean $(S E)$.
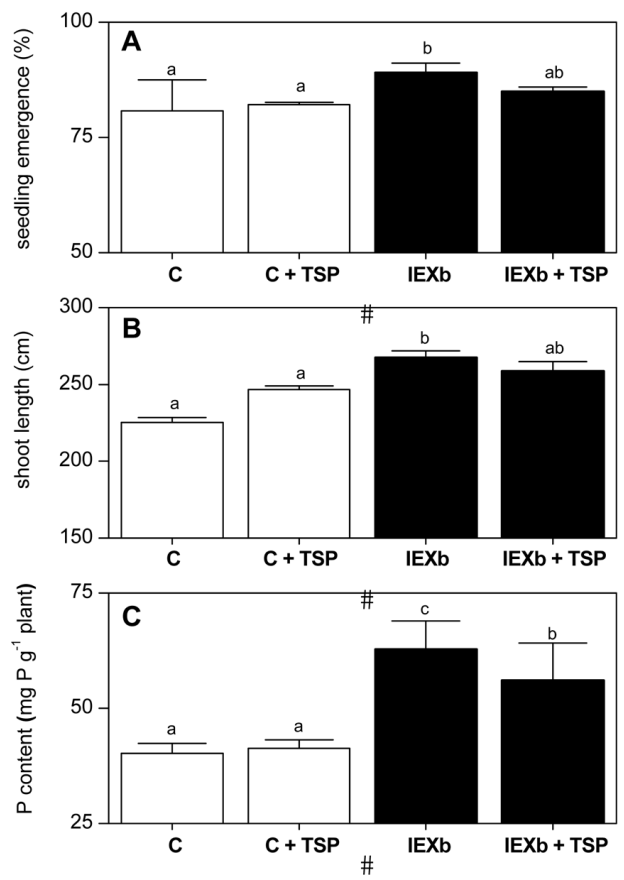

Figure. 2 Effects of inoculation of maize seeds with Pseudomonas tolaasii IEXb on growth parameters: seedling emergence (A), shoot length (B) and $\mathrm{P}$ content $(\mathrm{C})$ of maize plants grown under field conditions. White bar: uninoculated seeds without (C) or with triple superphosphate (C + TSP); black bars: seeds inoculated with IEXb or IEXb + TSP. Data represent mean \pm standard error of mean $(S E)$. 
The amount of total shoot dry matter in maize was higher in seed treated with IEXb bacterial strain $\left(2980 \mathrm{Kg} \mathrm{ha}^{-1}\right)$ than in the counterpart uninoculated control $\left(2132.7 \mathrm{Kg} \mathrm{ha}^{-1}\right)$, with a significant (32\%) increase in biomass production (Figure 3A). Regarding fertilized treatments, there were no significant differences between inoculated fertilized treatment (IEXb + TSP) and fertilized control (C + TSP).

Under unfertilized conditions, $P$. tolaasii IEXb caused a $45 \%$ increase in grain yield compared to the control (C) (Figure 3B). The treatment $\mathrm{IEXb}+$ TSP (9750.9 Kg ha-1) was statistically similar to $\mathrm{C}+\mathrm{TSP}$ treatment $(9904.7 \mathrm{Kg}$ $\mathrm{ha}^{-1}$ ), with $21 \%$ higher yield than that of its counterpart control $\left(8164.1 \mathrm{Kg} \mathrm{ha}^{-1}\right)$. There were significant differences in 1000-grain weight between treatments, and similar to the grain yield, the best performance was observed with IEXb without TSP (414.8 g), whereas the lowest values corresponded to the untreated control (348.8 g) (Figure 3C). Overall, P. tolaasii IEXb inoculation treatment without the application of TSP was more efficient in stimulating maize growth and yield than the other treatments, including the same bacterial treatment with TSP.
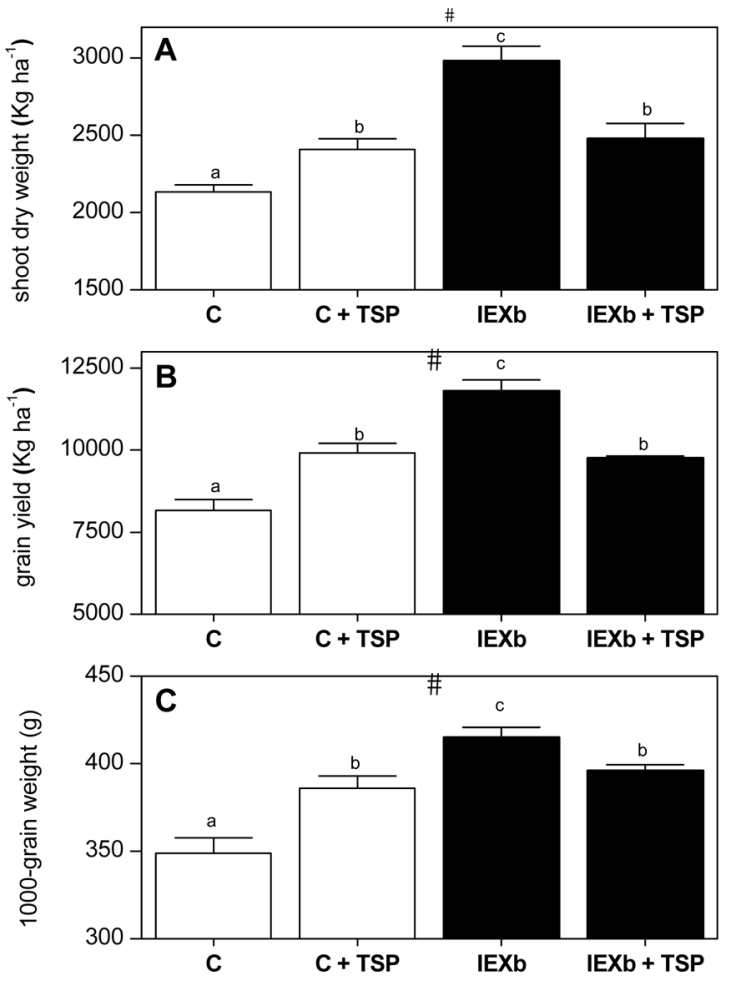

Figure. 3 Effects of Pseudomonas tolaasii IEXb inoculation in maize seeds on yield parameters: shoot dry weight (A), grain yield (B) and 1000-grain weight (C) of maize plants grown under field conditions. White bar: uninoculated seeds without (C) or with triple superphosphate (C + TSP); black bars: seeds inoculated with IEXb or IEXb + TSP. Data represent mean \pm standard error of mean $(S E)$. 


\section{Discussion}

The first stage of the experiment consisted of evaluating the effect of inoculating maize seeds with PSB in growth chamber. Two strains of the genus Pseudomonas and one strain of Panteoa had significant growth promoter effect on plant development. In general, seed inoculation with Pseudomonas tolaasii IEXb and Pantoea eucalytpi EV4 was found to have positive effects on aerial biomass, whereas inoculation with Pseudomonas koreensis SP28 increased the development of root biomass and $\mathrm{P}$ content in maize plants. This growth promoter effect could be attributed to the potential of these strains to increase the availability of nutrients, such as phosphorus, and siderophore and phytohormone production (Viruel et al., 2011), as well as to their capacity to colonize the root system and interact positively with the plant. Similar results of inoculation with strains of the genera Pseudomonas and Pantoea on several crops under controlled conditions have been reported (Carlier et al., 2008; Hu et al., 2010; Minaxi et al., 2013; Schoebitz et al., 2013; Yu et al., 2012). Pseudomonas aurantiaca JD37 was found to effectively colonize the rhizosphere and internal tissues of roots of maize and promote maize growth (Fang et al., 2012). Strains of Pseudomonas tolaasii have been reported as bacteria with biocontrol activity and plant growth promotion of rice (Adhikari et al., 2001) and showed ability to enhanced growth and yield of canola in the presence of cadmiun (Dell'Amico et.al., 2008). Pantoea dispersa 1A promoted shoot and root length, shoot and root dry biomass and N, P and $\mathrm{K}$ uptake on wheat with respect to uninoculated control (Selvakumar et al., 2008). Castagno et al., (2011) reported the ability of Pantoea eucalypti strains to solubilize phosphate and to promote plant growth in vitro onto Lotus tenuis. Notwithstanding, $P$. tolaasii is related to pathogenesis in cultivated mushrooms (Cuthi et al., 1984; Munsch et al., 2000) and $P$. eucalypti is related to plant diseases of maize and eucalyptus (Brady et al., 2009). Taking into account these backgrounds and the results of preliminary tests and growth chamber experiment, we selected the strain Pseudomonas tolaasii IEXb for the field trial.

The results of the field trial confirmed that $P$. tolaasii $\mathrm{IEXb}$ has a plant growth promoter effect on maize, as previously observed under controlled condition. The treatment inoculated with this bacterial strain improved the nutritional plant status, with the consequent significant increase in development of plant biomass and grain yield. Although $P$. tolaasii $\mathrm{IEXb}$ was found to have multiple plant growth promotion traits (Viruel et al., 2011), we may attribute the increased nutrient uptake primarily to auxin production by the bacterium (as IAA), which has a cascade effect on root development and nutrient uptake, and secondly to phosphate solubilization capacity, which increases soil $\mathrm{P}$ availability. Early P uptake leads to an increase in crop yield by stimulating plant growth and development (Richardson et al., 2009).

The results of the field trial revealed that the efficiency of this bacterial strain for improving growth and grain yield in maize was reduced with the application of $\mathrm{P}$ fertilizer to the soil. Only the control treatment showed a positive response to the chemical fertilizer. The inhibitory effect of the chemical fertilizer on the bioinoculant performance was already observed (Krey et al., 
2013; Shaharooma et al., 2008). In both cases, significant negative linear correlations were recorded between percentage of increase in plant growth and grain yield parameters caused by inoculating wheat and maize, respectively, and increasing levels of fertilizer application.

Increased plant growth and nutrient uptake as a consequence of inoculation of PSB under field conditions were also reported in wheat (Selvakumar et al., 2009; 2011), maize (Hameeda et al., 2008; Kumar et al., 2007), rice (Ashrafuzzaman et al., 2009; Sharma et al., 2014) and chickpea (Rudresh et al., 2005). There is currently a considerable interest in species of the genus Pseudomonas, which are being exploited for better crop production due to their rapid colonization, production of growth-promoting substances, and prevention of pathogen establishment in the rhizosphere through antibiosis, siderophore production or secretion of hydrolytic enzymes (Kumar et al., 2007; Selvakumar et al., 2009; Shaharooma et al., 2008). However, inoculation of maize with the Pseudomonas species studied in this work has still not been reported. In fact, to the best of our knowledge, this is the first report of the use of a Pseudomonas tolaasii strain as bioinoculant on maize in a field experiment. This work provides baseline information for future studies of PGPR candidates for development of bioinoculants to improve nutrient availability in soil, reduce chemical fertilizer application, minimize environmental pollution and promote an ecofriendly and low-input sustainable agriculture.

\section{Conclusion}

At present, the use of chemical fertilizers and manures cannot be eliminated without avoiding a consequent drastic decrease in food production. Hence, there is an urgent need for integrated management of nutrients that are incorporated into the soil as agricultural inputs to reduce the adverse environmental impacts of chemical fertilizers. The screening method used in growth chamber is an interesting technique to select the adequate bacterial strain for promoting growth in a particular crop and environment. These results also indicate that bacterial inoculation in maize seeds leads to a higher grain yield potential. In particular, P-solubilizing Pseudomonas tolaasii IEXb showed great potential for use as bioinoculant. The application of this bacterial strain had beneficial effects on growth, yield and $\mathrm{P}$ nutrition on maize plants. Regarding environmental pollution due to excessive use of chemical fertilizers and high costs of $\mathrm{P}$ fertilizer production, the bacterial strain tested may well be used as bioinoculant to enhance sustainable agricultural production. Our study also demonstrates the importance of evaluating potential growth-promoting bacteria under a variety of experimental conditions. These experiments, conducted both in growth chamber and in the field, are part of an ongoing project aimed at enhancing the use of this interesting technology to contribute to a sustainable agricultural system. 


\section{Acknowledgments}

This work was supported by Consejo de Investigación de la Universidad Nacional de Tucumán (CIUNT) and Instituto Nacional de Tecnología Agropecuaria (INTA). The authors are thankful to the Consejo Nacional de Investigaciones Científicas y Tecnológicas (CONICET) for providing a fellowship to Emilce Viruel.

\section{References}

Adesemoye, A.O., Kloepper, J.W. 2009. Plantmicrobes interactions in enhanced fertilizeruse efficiency. Appl. Microbiol. Biotechnol. $85,1-12$.

Adhikari, T.B., Joseph, C.M., Yang. G.P., Phillips. D.A., Nelson. L.M. 2001. Evaluation of bacteria isolated from rice for plant growth promotion and biological control of seedling disease of rice. Can J. Microbiol. 47, 916-924.

Ahemad, M., Khan, M.S. 2010. Plant growth promoting activities of phosphatesolubilizing Enterobacter asburiae as influenced by fungicides. Eurasia J. Biosc. 4, 88-95.

Ashrafuzzaman, M., Hossen, F.A., Ismail, M.R., Hoque, M.A., Islam, M.Z., Shahidullah, S.M., Meon, S. 2009. Efficiency of plant growth-promoting rhizobacteria (PGPR) for the enhancement of rice growth. Afr. J. Biotechnol. 8, 1247-1252.

Brady, C.L., Cleenwerck, I., Venter, S.N., Vancanneyt, M., Swings, J., Coutinho, T.A. 2009. Phylogeny and identification of Pantoea species associated with plants, humans and the natural environment based on mulitlocus sequence analysis (MLSA). Syst. Appl. Microbiol. 31, 447-460.

Carlier, E., Rover, M., Jaume, A.R., Rosas, S.B. 2008. Improvement of growth under field conditions, of wheat inoculated with Pseudomonas chloraphis sub sp. aurentia SR1. World J. Microbiol. Biotechnol. 24, 2653-2658.

Castagno, L.N., Estrella, M.J., Sannazzaro, A.I., Grassano, A.E., Ruiz, O.A. 2011. Phosphatesolubilization mechanism and in vitro plant growth promotion activity mediated by Pantoea eucalypti isolated from Lotus tenuis rhizosphere in the Salado River Basin (Argentina). J. Appl. Microbiol. 110, 11511165 .

Cuthi, S.S., Macauley, B J., Roberts, W.P. 1984. Characteristics of pathogenic nonfluorescent (smooth) and non-pathogenic fluorescent (rough) forms of Pseudomonas tolaasii and Pseudomonas gingeri. J Appl. Bacteriol. 57, 291-298

Dell'Amico, E., Cavalca, L., Andreoni, V. 2008. Improvement of Brassica napus growth under cadmium stress by cadmium resistant rhizobacteria Soil Biol. Biochem. 40, 74-84.

Di Rienzo, J.A., Casanoves, F., Balzarini, M.G., Gonzalez, L., Tablada, M., Robledo, C.W. 2011. InfoStat version 2011. Grupo InfoStat, FCA, Universidad Nacional de Córdoba, Argentina.

Fang, R., Lin, J., Yao, S., Wang, Y., Wang, J., Zhou, C., Wang, H., Xiao, M. 2012. Promotion of plant growth, biological control and induced systemic resistance in maize by Pseudomonas aurantiaca JD37. Ann. Microbiol. 63, 1177-1185. 
Fernández, L., Agaras, B., Zalba, P., Wall, L.G., Valverde, C. 2012. Pseudomonas spp. isolates with high phosphate-mobilizing potential and root colonization properties from agricultural bulk soils under notillmanagement. Biol. Fert. Soils. 48, 763773.

Hameeda, B., Harini, G., Rupela, O.P., Wani, S.P., Reddy, G. 2008. Growth promotion of maize by phosphate-solubilizing bacteria isolated from composts and macrofauna. Microbiol. Res. 163, 234-242.

Hinsinger, P., Brauman, A., Devau, N., Gérard, F., Jourdan, C., Laclau, J.P., Le Cadre, E., Jaillard, B., Plassard, C. 2011. Acquisition of phosphorus and other poorly mobile nutrients by roots. Where do plant nutrition models fail?. Plant Soil 348, 29-61.

Hoagland, D.R., Arnon, D.I. 1950. The waterculture method for growing plants without soil. Circular Calif. Agricul. Exper. Stat. Circ. 347 1-32.

Hu, X., Li, Z.J., Cao, Y.C., Zhang, J., Gong, Y.X., Yang, Y.F. 2010. Isolation and identification of a phosphate-solubilizing bacterium Pantoea stewartii subsp. stewartii g6, and effects of temperature, salinity, and $\mathrm{pH}$ on its growth under indoor culture conditions. Aquacul. Int. 18, 1079-1091.

Johnson, C.M., Ulrich, A. 1959. Analytical Methods for use in plant analysis II. Calif. Agric. Exp. Stn. Bull. 766, 26-27.

Kloepper, J.W., Schroth, M.N. 1981. Relationship of in vitro antibiosis of plant growth promoting rhizobacteria to plant growth and the displacement of root microflora. Phytopathol. 71, 1020-1024.
Krey, T., Vassilev, N., Baum, C., EichlerLöbermann, B. 2013. Effects of longterm phosphorus application and plantgrowth promoting rhizobacteria on maize phosphorus nutrition under field conditions. Eur. J. Soil Biol. 55, 1124-1130.

Kumar, B., Trivedi, P., Pandey, A. 2007. Pseudomonas corrugata: A suitable bacterial inoculant for maize grown under rainfed conditions of Himalayan region. Soil Biol. Biochem. 39, 3093-3100.

Minaxi, Saxena, J., Chandra, S., Nain, L. 2013. Synergistic effect of phosphate solubilizing rhizobacteria and arbuscular mycorrhiza on growth and yield of wheat plants. J. Soil Sci. Plant Nutr. 13, 511-525.

Munsch, P., Geoffroy, V.A., Alatossava, T., Meyer, J.M. 2000. Application of siderotyping for characterization of Pseudomonas tolaasii and "Pseudomonas reactans" isolates associated with brown blotch disease of cultivated mushrooms. Appl Environ. Microbiol. 66, 4834-4841.

Murphy, J., Riley, J.P. 1962. A modified single solution method for the determination of phosphate in natural waters. Anal. Chim. Acta. 27, 31-36.

Richardson, A.E., Hocking, P.J., Simpson, R.J., George, T.S. 2009. Plant mechanisms to optimize access to soil phosphorus. Crop Pasture Sci. 60, 124-143.

Rodríguez, H., Fraga, R. 1999. Phosphate solubilizing bacteria and their role in plant growth promotion. Biotechnol. Adv. 17, 319339. 
Rudresh, D.L., Shivaprakash, M.K., Prasad, R.D. 2005. Effect of combined application of Rhizobium, phosphate-solubilizing bacterium and Trichoderma spp. on growth, nutrient uptake and yield of chickpea (Cicer arietinum L.). Appl. Soil Ecol. 28,139-146.

Schoebitz, M., Ceballos, C., Ciamp, L. 2013. Effect of immobilized phosphate solubilizing bacteria on wheat growth and phosphate uptake. J. Soil Sci. Plant Nutr. 13, 1-10.

Selvakumar, G., Joshi, P., Nazim, S., Mishra, P.K., Bisht, J.K., Gupta, H.S. 2009. Phosphate solubilization and growth promotion by Pseudomonas fragi CS11RH1 (MTCC 8984) a psychrotolerant bacterium isolated from a high altitude Himalayan rhizosphere. Biologia. 64, 239-245.

Selvakumar, G., Joshi, P., Suya, L.P., Mishra, P.K., Joshi, G.K., Bisht, J.K., Bhatt, J.C., Gupta, H.S. 2011. Pseudomonas lurida M2RH3 (MTCC9245), a psychrotolerant bacterium from the Uttarakhand Himalayas, solubilizes phosphate and promotes wheat seedling growth. World J. Microbiol. Biotechnol. 27, 1129-1135.

Selvakumar, G., Kundu, S., Joshi, P., Nazim, S., Gupta, A.D., Mishra, P.K., Gupta, H.S. 2008. Characterization of a cold-tolerant plant growth promoting bacterium Pantoea dispersa $1 \mathrm{~A}$ isolated from a sub-alpine soil in the North Western Indian Himalayas. World J. Microbiol. Biotechnol. 24, 955-960.

Shaharooma, B., Naveed, M., Arshad, M., Zahir, Z.A. 2008. Fertilizer-dependent efficiency of Pseudomonads for improving growth, yield, and nutrient use efficiency of wheat (Triticuma estivum L.). Appl. Microbiol. Biotechnol. 79, 147-155.
Sharma, A., Shankhdhar, D., Sharma, A., Shankhdhar, S.C. 2014. Growth promotion of the rice genotypes by pgprs isolated from rice rhizosphere. J. Soil Sci. Plant Nutr. 14, 505-517.

Tomei, J., Upham, P. 2011. Argentine clustering of soy biodiesel production: the role of international networks and the global soy oil and meal markets. Open Geogr. J. 4, 45-54.

Velasco, J.L., Sainz Rozas, H., Echeverría, H.E., Barbieri, P.A. 2012. Optimizing fertilizer nitrogen use efficiency by intensively managed spring wheat in humid regions: Effect of split application. Can. J. Plant Sci. 92, 847-856.

Vessey, K. 2003. Plant growth promoting rhizobacteria as biofertilizers. Plant Soil. 255, 571-586.

Viruel, E., Lucca, M.E., Siñeriz, F. 2011. Plant growth promotion traits of phosphobacteria isolated from Puna, Argentina. Arch. Microbiol. 193, 489-496.

Yu, X., Liu, X., Zhu, T.H., Liu, G.H., Mao, C. 2012. Co-inoculation with phosphatesolubilizing and nitrogen-fixing bacteria on solubilization of rock phosphate and their effect on growth promotion and nutrient uptake by walnut. Eur. J. Soil Biol. 50, 112117. 
